\title{
Essay \\ Studying and Challenging Racism in Higher Education: Naming Bad Faith to Understand the "Logic" of Racism
}

\author{
Antar A. Tichavakunda
}

\author{
Department of Education Leadership, University of Cincinnati, Cincinnati, OH 45221, USA; \\ tichavaa@ucmail.uc.edu
}

\begin{abstract}
In this conceptual essay, the author argues that bad faith is a valuable concept in understanding and challenging racism in higher education. The philosopher Lewis Gordon argues that racism is a manifestation of bad faith. For the actor who sees Black people as less than human, for example, no evidence will allow the actor to see otherwise. Bad faith is the disavowal of any disconfirming evidence which allows actors to maintain their worldviews. The author draws from high profile examples of racism in higher education as conceptual cases to make his argument. Specifically, the author demonstrates how attacks upon Critical Race Theory in education, the currency of critiques of microaggressions research, and the perennial difficulty to name racist violence on campus as hate crimes operate upon a logic of racism through bad faith.
\end{abstract}

Keywords: racism; higher education; Critical Race Theory in education

\section{Introduction}

Citation: Tichavakunda, A.A. Studying and Challenging Racism in Higher Education: Naming Bad Faith to Understand the "Logic" of Racism. Educ. Sci. 2021, 11, 602. https:// doi.org/10.3390/educsci11100602

Academic Editors: Sylvia Hurtado and Krystle Palma Cobian

Received: 14 August 2021

Accepted: 27 September 2021

Published: 30 September 2021

Publisher's Note: MDPI stays neutral with regard to jurisdictional claims in published maps and institutional affiliations.

Through volumes of rigorous scholarship, the eminent sociologist and advocate for racial justice, W.E.B. Du Bois, sought to systematically combat racist ideas and narratives about Black people. He realized that research, however rigorous, would not always alter the beliefs of the racist [1]. Du Bois argued, "... in the fight against race prejudice, we were not facing simply the rational, conscious determination of white folk to oppress us; we were facing age-long complexes sunk now largely to unconscious habit and irrational urge" (p. 296), as cited by [1]. As students, educators, student affairs leaders, and scholars, higher education stakeholders invested in racial justice are no strangers to the seemingly irrational racist acts and illogical justifications of racist behavior and discourses.

Centuries ago, the existentialist philosopher Søren Kierkegaard posed pertinent, related questions about self-deception and the irrational:

Whose recovery is more doubtful, that of the one who does not see, or that of the person who sees and yet does not see? What is more difficult - to awaken someone who is sleeping or to awaken someone who, awake, is dreaming that he is awake? [2]

The rhetorical questions he poses urge the reader to face the herculean task, if not impossibility, of generative conversation with someone who is stubbornly, and incorrectly, certain of their own beliefs. In this unique moment of virality, the echo rooms of social media, and suspicion of the news media, no shortage of examples exist of those who believe that they see, but do not see. Despite all the evidence otherwise, people continue to suggest the Earth is flat, people continue to deny COVID-19's existence, and people continue to suggest that the 2020 presidential election in the USA was fraudulent.

We are met with a similar quandary in higher education. Rigorous research, evidence, and the power of logic are valuable tools to challenge racist systems and racists, themselves. Yet, how does one engage the irrational, persuade the illogical, or debate the incorrigible? I remain curious, for example, about the possibility of altering the racist views of people who sincerely and wrongly believe their views are just and right, the furthest thing from racist. 
Although out of scope for the present paper, it is worth noting that useful work has examined the role of social networks and the proliferation of misinformation and conspiracy theories online [3-5]. Such literature examines the processes of how hateful or false information is spread. Further, in this work, I do not offer an answer of how to change the minds of people with oppressive ideologies, who deceive themselves into thinking they are in fact liberatory and equitable. I do, however, offer an underutilized concept in higher education to name and identify the irrational stances of such actors-bad faith. To be clear, scholars have already compellingly theorized racism as a form of bad faith [6]. I build upon this foundational work to apply the concept of bad faith to the study of racism in the higher education context. This theoretical paper engages with one central question:

How is the concept of bad faith useful in understanding racism and the struggle for racial justice in higher education?

Using Critical Race Theory's valuation of counter-storytelling, I argue that many dominant, racist narratives about race and higher education are steeped in bad faith. Further, bad faith presents an obstacle to productive conversations surrounding research. Understanding such dominant narratives as acts of bad faith, I suggest that bad faith (1) complicates understandings of counternarratives and dominant narratives and (2) redirects and protects the intellectual and activist energy of higher education stakeholders.

In what follows, I introduce and explain the concept of bad faith and its relevance to studying and fighting racism in higher education. I provide three examples of racism as a form of bad faith in higher education: (1) the right-wing attack upon CRT, (2) popular critiques of microaggressions research, and (3) the struggle of naming a crime as racially motivated in the higher education context. I use these examples as conceptual cases to demonstrate bad faith's usefulness in naming racism and understanding the hold of dominant, racist stories on society.

\section{Bad Faith and Evidence of Racism}

Bad faith-similar to evidence-has legal connotations and is a term used to describe an intentionally dishonest act one commits in a legal obligation or contractual agreement. Following the work of the philosopher Lewis Gordon, I draw from the existentialist conception of bad faith. Echoing Gordon's work, I suggest that bad faith provides insight to the study of racism and the struggle for racial justice.

\subsection{Understanding Bad Faith}

Jean-Paul Sartre, a French existentialist philosopher, coined the term "mauvaise foi", or bad faith, to describe peoples' tendency to lie to themselves in order to maintain a positive self-image or protect their individual feelings [7]. The idea of bad faith assumes that humans are aware, reflexive, and to a certain extent, have agency. Through bad faith, we lie to ourselves and "hide from what we are on the basis of shady evidence" [6] (p. 12).

Sartre suggests that people deceive themselves in order to avoid facing the anguish of their freedom [7]. Sartre uses the example of a waiter who convinces himself that all he can be in life is a waiter. In reality, however, he has other options. The reality of such options and the harsh reality that he, himself, is foreclosing different life courses, would be too harsh of a reality to accept. The waiter, then, lies to himself in order to avoid this anguish and make his life simpler with a façade of singular life path. Thus, when people are in bad faith, they deceive themselves in order to embrace a lie that keeps their self-image or worldview intact.

\subsection{Understanding the Connection between Bad Faith and Racism}

Evidence plays a central role in understanding bad faith and racism. Racism, and anti-Black racism in particular, Gordon argues, is a manifestation of bad faith. Racists, for example, are in bad faith by deceiving themselves into believing in their inherent superiority to another group of people. Through non-persuasive evidence, racists can convince themselves that people constructed as other races are less than human. As 
such, the only evidence that can upend a racist person's belief that they are inherently superior must be "absolute, immutable, perfect-which amounts to saying that every single member of the condemned race must be without fault" [6] (p. 76). Of course, such evidence cannot exist.

As Gordon argues, the racist " ... is unwilling to accept what ordinarily count as counter-examples where questions of race are concerned. He has decided to resist persuasion" [6] (p. 75). In other words, for the actor who sees Black people as less than human, no evidence of any form will allow the actor to see otherwise. Bad faith is the disavowal of any such disconfirming evidence, which allows people to maintain their worldviews at all costs. While not under the name of bad faith, an appreciable amount of literature examines the irrationality and illogical nature of White people's racism towards people of color [8].

Certainly, people are not born racist. Nothing is natural about race, and groups do not inherently have racist beliefs. Rather, racism is a force that shapes "a social system organized around practices, mechanisms, cognitions, and behaviors that reproduce racial domination" [9] (p.2). At the same time, racism is both macro and micro, institutional and individual, material and symbolic, outright and subtle, as well as structural and intrapersonal [10]. Regardless of the manifestation, racism is connected to a larger structure of white supremacist domination [9]. As such, racism as a manifestation of bad faith is not a spontaneous product of its own, but rather a product of a legacy of racial domination and socialization into a racist societal order.

\subsection{The Problem of Bad Faith and Proving Racism}

Examples of bad faith attitudes towards evidence of racism and the humanity of Black people abound. Consider cases where seemingly perfect evidence was not enough to convict or indict police officers' extreme force against unarmed Black people. Mainstream media, for example, saw the video evidence of police officers punching and beating Rodney King with batons as "objective", "without bias", "impartial", and "beyond rebuttal" [11]. Despite the clear evidence of excessive force, the court did not find the officers guilty of excessive force.

My point here is that evidence is far from objective. Rather, evidence has been used or ignored to the detriment of many Black people. Bad faith and racial biases of the judge and jurors also play a role in the value of evidence. Another example can be found in the controversial case against George Zimmerman, who shot and killed Trayvon Martin, a Black teenager. Rachel Jeantel, a friend of Martin's, was a key witness for the case against Zimmerman. Her important testimony, however, was rendered incomprehensible and dismissed as not credible largely because of her Blackness and her use of African American Vernacular English [12].

The idea that the legal system is incapable of identifying or recognizing evidence of subtle forms of racism is not new [13-15]. As Critical Race scholars show, the legal field is far from immune to racism [16-19]. Legal scholars have critiqued the justice system's enforcement of the Equal Protection Clause for decades, arguing that courts take the position that they cannot identify discriminatory effect if they cannot identify discriminatory intent. The courts' decision to judge cases of racial discrimination on intent has made it nearly impossible to deem an infraction racist without an offender's admittance of racist motivations [14]. Unconscious racism, as legal theorists such as Sheri Johnson and Charles Lawrence have argued $[14,15]$, is a central limitation in jurisprudence concerning racial discrimination. In sum, evidence, in the legal field, means little in cases involving racism.

Racially motivated violence or crimes, for example, are markedly difficult to prosecute [13]. Although courts are equipped to criminalize extremist violence from the $\mathrm{Ku}$ Klux Klan and neo-Nazi groups, they are less equipped to engage with the hate crimes committed by the average American. Short of an admittance of racist intent, courts struggle with naming racially motivated crimes. Racism, as Johnson clarifies, is not a taboo topic in the law. Rather, the difficulty of taking stock of the reality of unconscious, subtle racism 
is laden in "ignorance, fear, and denial" [14] (p. 1027). The professed need to identify the racist intent of an offender before recognizing an action as racist in addition to the inability to acknowledge unconscious racism is, similarly, an example of society's bad faith attitudes towards evidence of racism.

\section{Where I Enter}

No research is absent of a researcher. I am a cisgender Black man who employs CRT in addition to other critical, sociological theoretical frameworks to study how race and racism shapes higher education. In my work, I do not question if race matters or debate the existence of racism. Rather, I approach my work with the assumption that race is permanent and at play in all social situations and systems [16].

My positionality as a Black person navigating predominantly White spaces and as a scholar studying Black students, in particular, has led me to question how evidence can both be used in the pursuit of but also as an obstacle to racial justice. I have lost many hours trying to understand the illogical justifications people and systems use to justify anti-Black violence and oppression. The concept of bad faith, although certainly not a solution to anti-Black racism, has offered me a better understanding of both the permanence of racism and the hold irrational stock stories of race and racism have on society. I write this to say that I am neither dispassionate nor detached from the cases I highlight in the next section.

\section{Three Cases of Bad Faith and Majoritarian Stories}

Bad faith is a useful concept both for the study of race, diversity, and higher education, as well as for the struggle for racial justice in the higher education context. Consider, however, what I have presented about bad faith thus far. Bad faith in the form of racism manifests as unconscious self-deception, allowing the racist to maintain their worldview and a positive sense of self regardless of any counter-evidence. No amount of evidence or logic can convince the racist that their beliefs about race are incorrect or immoral. How, then, is bad faith, a concept that questions the utility of evidence, persuasion, and rigorous scholarship, useful?

For the higher education practitioner and scholar, bad faith provides scholarly and pragmatic utility. From a scholarly lens, bad faith, as a concept, lends explanatory power for understanding certain issues of racism. From a practical lens, being able to identify bad faith provides a mode of protecting one's energy and well-being in the struggle for racial justice. To illustrate these points, I provide three conceptual cases demonstrating the interconnected nature of bad faith, racism, and higher education. Each case might be understood as what Critical Race Theorists might call a stock story or a majoritarian or dominant narrative [20].

CRT is an intellectual and social justice project equipped with conceptual tools to name, analyze, and challenge racism in society. CRT emerged in the legal field and has since made its way across disciplines, developing unique tools and propositions to understand and challenge racism [21]. While CRT work is diverse, all Critical Race Theorists are preoccupied with analyzing the role of racism in society and fighting for racial justice. Similarly, Critical Race Theorists also acknowledge the structuring role of narratives in reproducing and disrupting racism.

Narratives hold together social worlds and how we understand them. Dominant narratives about race and racism work to serve and reproduce a White supremacist society. Solórzano and Yosso [22], for example, define majoritarian or dominant narratives as "one that privileges Whites, men, the middle and/or upper class, and heterosexuals by naming these social locations as natural or normative points of reference" (p. 28). Such narratives are commonly understood to be objective despite being undergirded by oppressive ideologies. Majoritarian stories can take many forms, from research, to legal documents, to theories, to first-person accounts [18,21]. In different ways, the three cases I highlight next are examples of majoritarian narratives. 
In what follows, I use the concept of bad faith to briefly analyze (1) the right-wing attack upon Critical Race Theory, (2) critiques of microaggressions research, and (3) the difficulty of finding a crime racially motivated in higher education. For each case, I will first provide context, offering a description of the case. In doing so, I will make clear the case's pertinence to the higher education context. Then, I will analyze the case using bad faith as a central concept.

\subsection{Bad Faith and the Attack on Critical Race Theory}

Critical Race Theory (CRT) is under attack by many conservative thinkers and politicians [23]. The bad faith attack on CRT, or "Crit-baiting" as the Critical Race Theorist Kimberlé Crenshaw calls it, is not new [17]. Yet, the attack on CRT has become far more pronounced since the Trump presidency. CRT's detractors argue that the theory is unduly divisive, preaches racial hate, is un-patriotic, and will negatively impact students' education. Across the nation, concerned parents storm schoolboard meetings protesting what they believe to be is CRT in their students' classrooms [24]. As of July 2021, lawmakers across 26 states have introduced bills to legislatures to restrict teaching CRT and/or discussing identity in K-16 classrooms [25]. Eleven of these states have successfully passed and signed such bills into laws or enacted bans through different mechanisms teaching CRT or identity in a critical manner.

The attacks upon and fearmongering around CRT have implications for higher education. As a theory, CRT has made waves in higher education scholarship, providing an essential framework of understanding race and racism in the university context [26]. Yet, talk of banning CRT will endanger any course that remotely discusses race/racism or other critical issues of diversity in higher education. For example, courses have already been cancelled and professors continue to be targeted for teaching courses that are related to critical thought and diversity, more generally [23]. A website is even dedicated to providing a resource for "parents and students concerned about the negative impact Critical Race Training has on education" [27] (par. 1). The database includes over 350 colleges and includes the names of courses, trainings, initiatives, and university statements that are supposedly linked to CRT.

\section{Identifying Bad Faith}

Recent detractors of CRT, I suggest, are often in bad faith. Detractors believe that CRT is evil, hate-filled, racist, psychological abuse and whatever else influential conservative speakers and politicians have suggested [28]. Of course, belief is not always the same as empirical knowledge. The actor in bad faith, however, equates their belief to knowledge or fact. The actor in bad faith believes CRT is hateful, therefore it must be hateful. No amount of evidence can counter this belief, which, in the bad faith actor's mind, is equivalent to fact.

The articles in response to and critiquing CRT fear mongering are incisive, irrefutable, and unquestionably necessary [29]. Such articles set the record straight for those who are genuinely curious about CRT and are not in bad faith towards CRT. Yet, for the politician, scholar, social media influencer, conservative television personality, or parent who is in bad faith, logic, evidence, and rationality will not matter.

Beyond the negative adjectives ascribed to CRT by detractors, consider the "examples" of CRT critics uses in their arguments [27]. According to such critics, the 1619 project is a form of CRT. Ibram Kendi is a leading Critical Race Theorist. CRT is a form of Marxism. All these things are false. The description of CRT provided on the website tracking where CRT is allegedly taught does not include the name of one Critical Race Theorist or one reference to legitimate CRT scholarship. Alternatively, consider how the education scholar and public intellectual, Marc Lamont Hill, on multiple occasions, has debated detractors of CRT who could not name one CRT scholar or even define CRT [30]. It is abundantly clear that most vocal detractors of CRT do not know what CRT is. 
Identifying critics who are in bad faith is useful because we know that no amount of evidence will convince them otherwise of their beliefs. In the case of CRT, the critic in bad faith deceives themselves into believing that CRT is hate-filled and should not be taught. They lie to themselves, however, to preserve their world view. To embrace CRT or engage with the theory in good faith might push them to look at themselves or their country in a negative manner. As Gordon argues, " ... under the model of bad faith, the stubborn racist has made a choice not to admit certain uncomfortable truths about his group and chooses not to challenge certain comfortable falsehoods about other people" [6] (p. 75). Bad faith critics are likely clutching to pleasing falsehoods that they might tell themselves. The comfortable lies they tell themselves might be, "The United States' founding fathers were great men and America is the best country," or "I worked hard to get where I am and race has nothing to do with it." The critic in bad faith will resist anything, CRT included, that might upset their beliefs and negatively impact their world view.

\subsection{Bad Faith and Critiques of Microaggressions Research}

Microaggressions, a core concept in the study of experiential racism, provides a name for subtle visual, verbal, and nonverbal insults about race that can contribute to peoples' feelings of marginalization [31]. Research on microaggressions has proved foundational to understanding how race is felt and subtle forms of racism in higher education. By studying how racism is experienced and felt, higher education stakeholders gain greater insight into an integral force of racism as a larger structure. Despite, or perhaps because of, a wealth of literature concerning the deleterious impacts of microaggressions on students of color in higher education [31-33], critics - citing a lack of evidence-are taking aim at microaggressions research [34].

A chorus of scholars, free speech activists, and conservative thinkers railing against microaggressions research and programs has increased in intensity over the past decade. In peer-reviewed journals, microaggressions research has even been called the "unwisest idea" in higher education [35]. Scholars critiquing research on microaggressions wield the concept of evidence to question the experiential reality of racism through microaggressions research [34,35]. Scott Lilienfeld's (2017) "Microaggressions: Strong Claims, Inadequate Evidence", in a leading psychology journal, provided 18 recommendations to increase the rigor of microaggressions research and boldly called for a complete moratorium on microaggressions workshops.

Drawing from psychology, cognitive science, and social cognition, Lilienfeld engages in a methodological and conceptual assessment of the microaggressions research project. Based on his review, he suggests that the concept of microaggressions is hinged on premises that are not supported by "scientific evidence" [34] (p. 140). Lilienfeld argues that his intention is not to suggest that microaggressions research is irrelevant or unimportant, but to increase rigor in order "to ensure that the strength of scientific assertions regarding microaggressions is roughly proportional to the strength of the scientific evidence" [34] (p. 160). Such arguments, if blithely accepted, would have clear implications for diversity and higher education.

\section{Identifying Bad Faith}

Scholars have penned forceful and compelling critiques of Lilienfeld's article [36-38]. Although out of bounds to describe all the problematics of Lilienfeld's work, a key theme was Lilienfeld's lack of engagement with the voluminous research on microaggressions.

Consider, for example, Lilienfeld's argument that microaggressions research " ... overlooks the possibility-indeed, the probability-that individual differences color recipients' interpretations of, and reactions to, microaggressions" [34] (p. 159). A cursory search counters this claim, as research indeed examines the heterogeneity of how people of color interpret and respond to race-based stereotypes or microaggressions [39,40]. Further, Williams [37], in her incisive critique, demonstrates the various areas where Lilienfeld overlooked bodies of research that would also counter his points. 
Bad faith attitudes towards racism allows a scholar such as Lilienfeld to ask for greater evidence concerning the microaggressions research project without himself providing evidence of a systematic literature review of microaggressions research [34]. Similar to the trials concerning racism, we are to take Lilienfeld's word, by itself, that he reviewed the literature as evidence enough.

I suggest that the aforementioned detractors of microaggressions research are in bad faith. They believe microaggressions research lacks evidence, and therefore no amount of evidence or argumentation can alter their thinking. Lilienfeld, in a response to Williams' rebuttal [37], evaded engaging with the substance of Williams' argument [38]. Consider Williams' reflection upon seeing Lilienfeld's response:

I was disappointed to see that one of his main strategies to address my points was to take statements from several coherent arguments within my article and paste them together in a way that makes it appear that I contradict myself, rather than constructive scientific engagement with the larger issues I raise ... [38] (p. 39)

Williams points out other instances where Lilienfeld only engaged with her article partially for the purpose of serving his argument against microaggressions [38]. Lilienfeld's lack of a fair engagement with Williams' argument, I suggest, is a manifestation of bad faith. In other words, Lilienfeld deceives himself into believing his argument against microaggressions is correct by not facing Williams' counter arguments.

\subsection{Bad Faith and the Elusive Evidence of Hate Crimes in Higher Education}

Anti-Black violence is not uncommon in higher education [41]. In this section, however, I briefly describe three examples of anti-black violence in higher education where the justice system became involved. I highlight these cases because, despite the compelling evidence presented otherwise, none of the cases were ruled to be racially motivated or hate crimes.

A White man murdered Richard Collins III, a Black man and Bowie State University student, at a University of Maryland College Park bus stop on 20 May 2017 [42]. The murderer was a member of a hateful Facebook group that espoused racist, sexist ideology. The judge found the man guilty of murder but not of a hate crime. In another case, on September 2019, two White men attending the University of Arizona beat a fellow student, a Black man, near a campus residence hall [43]. They called him the n-word multiple times while punching and kicking him. No hate crime was charged.

In 2013, at San Jose State University, three White students engaged in anti-Black violence, bullying their Black roommate. The White students were later brought to trial for bullying Donald Williams Jr. The three White men forcibly clamped a U-shaped lock around Williams' neck, hung a Confederate flag in their shared common space, and called him "fraction" and "three-fifths" in reference to the Three-Fifths Compromise of 1787 [44]. In an apology to Williams, one of the White men said, "I am truly sorry that any of this happened. It was certainly insensitive and offensive, but it was not racially motivated" [45] (par. 12). A jury of six non-Black people found three men guilty of misdemeanor battery but not of a hate crime.

\section{Identifying Bad Faith}

Frantz Fanon stated, "Race prejudice in fact obeys a flawless logic. A country that lives, draws its substance from the exploitation of other peoples, makes those peoples inferior. Race prejudice applied to those peoples is normal", as cited by [6] (p. 71). Fanon's words provide insight to how the cases I discussed were not deemed racially motivated hate crimes. The man who was a member of a racist Facebook group is not deemed racist, for example, because his racist behavior might be considered the norm in a racist society-not quite racist enough to be called a hate crime. Concerning the difficulty of finding someone guilty of racism and a hate crime, the words of the essayist Ta-Nehisi Coates are pertinent: "... the bar for racism has been raised so high that one need to be a card-carrying member of the Nazi party to qualify" [46] (par. 13). 
The San Jose State case is a particularly striking example of bad faith and racism. Despite the evidence presented and Williams' belief that his roommates' actions were racially motivated, bad faith towards evidence of the students' racism prevailed. In this case, evidence was far from a useful metric or lens of studying and naming racism. To the contrary, one might argue that evidence was used to protect White students from a harsher sentence rather than providing an accurate portrait of the racist nature of the incidents. Such cases provide an example of the limits of evidence in studying racism. Simply because White students suggested they had no racist motivation, their racist actions were rendered race neutral.

\section{Conclusions}

Given the permanence of racism, stock stories, and dominant narratives about marginalized populations, race, and racism will continue. Critical Race Theorists and those pursuing racial justice will continue to challenge such racist narratives and ideologies. Although the struggle will continue, it is useful for higher education stakeholders to understand how and why racist ideologies persist despite their work dispelling, debunking, and critiquing racist beliefs. As I demonstrated above, bad faith provides an answer to how racist beliefs, research, and narratives persist even with sound counter-evidence.

How do otherwise unbelievable dominant narratives about racially marginalized people persist? Bad faith. For people who deceive themselves in order to maintain a positive self-image or world view, dominant narratives around race and racism align with and reinforce their racist beliefs. Echoing prior work [20,22], I suggest that dominant narratives do not persist because we simply do not have the right type or enough counter narratives. Rather, racism as bad faith renders any and all counternarratives ineffective for changing the hearts and minds of some racists.

Does this mean that we give up in our efforts to challenge racist thinking and policies? Certainly not. The work we do in attempting to set the record straight about race, from microaggressions to the project of CRT, is valuable and needed. Providing counterevidence or a counter story for a racist, dominant narrative is important. This work, however, is not for the author of the racist story. Rather, the work is important for onlookers and those who are genuinely curious. Concerning CRT, Kimberlé Crenshaw, for example, notes, "If we were to respond to all of our detractors, we would probably do little else" [47] (p. 1369). Silence or resignation, however, is not the answer. Rather, Crenshaw argues for greater organization in communicating our work:

We need to determine how to translate our work better, to intervene in ways that help model interventions at the local level, to show people what a difference critical race thinking makes in their own workplaces and communities. [47] (p. 1369)

This work is a necessary project. My point in identifying bad faith arguments and attacks, however, is useful in strategizing how, if at all, one decides to respond to detractors and how to make sense of otherwise illogical justifications of racist actions.

Our energy — physical, emotional, and intellectual alike—is finite [48]. When attuned to bad faith in racist arguments, equity-minded higher education stakeholders might better direct and protect their energy. As equity-minded scholars, we might better select which battles are worth fighting and debates worth having when we are able to name bad faith. We might further understand why some of our arguments and initiatives, however thoughtful, seem to leave detractors unmoved. Consider, again, the example about detractors of CRT. Stating the facts about CRT is necessary, but debating with someone who is against CRT but does not care to learn what CRT is can also be a waste of time or energy.

As higher education stakeholders interested in equity work, we might take cues from the poet and essayist, June Jordan:

We do not sweat and summon our best in order to rescue the killers; it is to comfort and to empower the possible victims of evil that we do tinker and daydream and revise and 
memorize and then impart all that we can of our inspired, our inherited humanity as cited by. [49] (p. xxiii)

To what extent is our equity work directed at those in bad faith? Policies, initiatives, and energy might be more usefully directed to supporting the victims of racism rather than attempting to change the mindsets of the racists.

Will identifying bad faith solve racism? Certainly not. Yet, identifying bad faith arguments and narratives around racism provides a useful tool for the scholar and practitioner working with equity in mind. Consider the concept of racial realism [16]. The Critical Race Theorist, Derrick Bell, theorized racial realism as a call to "get real" about racism and the fact that racism is permanent. Bell argued that a racial realist perspective "enables us to avoid despair, and frees us to imagine and implement racial strategies that can bring fulfillment and even triumph" [16] (pp. 373-374). In a similar manner, identifying bad faith arguments and narratives helps us come to terms with the endurance of racism as well as the impossibility of changing the minds of some people or changing the foundations of racist structures. To be clear, I am not suggesting that identifying bad faith relieves us of doing equity-oriented work. Rather, identifying those acting in bad faith aids us in avoiding demoralization if our results do not match our efforts. With the advent of bad faith as racism, we are compelled to ask, what new strategies might we employ to fight for racial justice?

Funding: This research received no external funding.

Acknowledgments: Thank you to the reviewers and special edition editors for their thoughtful feedback.

Conflicts of Interest: The author declares no conflict of interest.

\section{References}

1. Holt, T.C. Marking: Race, race-making, and the writing of history. Am. Hist. Rev. 1995, 100, 1-20. [CrossRef]

2. Kierkegaard, S. Works of Love. Kierkegaard's Writings, XVI; Hong, H.V.; Hong, E.H., Translators; Princeton University Press: Princeton, NJ, USA, 1995; (Original work published 1847).

3. An, J.; Quercia, D.; Cha, M.; Gummadi, K.; Crowcroft, J. Sharing political news: The balancing act of intimacy and socialization in selective exposure. EPJ Data Sci. 2014, 3, 1-21. [CrossRef]

4. $\quad$ Enders, A.M.; Uscinski, J.E.; Seelig, M.I.; Klofstad, C.A.; Wuchty, S.; Funchion, J.R.; Murthi, M.N.; Premaratne, K.; Stoler, J. The Relationship Between Social Media Use and Beliefs in Conspiracy Theories and Misinformation. Political Behav. 2021, 1-24. [CrossRef]

5. Sikder, O.; Smith, R.E.; Vivo, P.; Livan, G. A minimalistic model of bias, polarization and misinformation in social networks. Sci. Rep. 2020, 10, 1-11. [CrossRef]

6. Gordon, L.R. Bad Faith and Antiblack Racism; Prometheus Books: Amherst, NY, USA, 1999.

7. Sartre, J.-P. Being and Nothingness: An Essay on Phenomenological Ontology; Routledge: London, UK, 1943.

8. Leonardo, Z. The souls of white folk: Critical pedagogy, whiteness studies, and globalization discourse. Race Ethnnicity Ed. 2002, 5, 29-50. [CrossRef]

9. Bonilla-Silva, E. Feeling race: Theorizing the racial economy of emotions. Am. Soc. Rev. 2019, 84, 1-25. [CrossRef]

10. Essed, P. Understanding Everyday Racism: An Interdisciplinary Approach; Sage: Newbury Park, CA, USA, 1991.

11. Stuart, F. Constructing police abuse after Rodney King: How skid row residents and the Los Angeles Police Department contest video evidence. Law Soc. Inq. 2011, 36, 327-353. [CrossRef]

12. Rickford, J.R.; King, S. Language and linguistics on trial: Hearing Rachel Jeantel (and other vernacular speakers) in the courtroom and beyond. Language 2016, 92, 948-988. [CrossRef]

13. Hernandez, T.K. Bias crimes: Unconscious racism in the prosecution of "racially motivated violence". Yale Law J. 1990, 99, 845-864. [CrossRef]

14. Johnson, S.L. Unconscious racism and the criminal law. Cornell Law Rev. 1987, 73, 1016-1037.

15. Lawrence, C., III. Unconscious racism revisited: Reflections on the impact and origins of the id, the ego, and equal protection. Conn. Law Rev. 2007, 40, 931-977.

16. Bell, D.A. Racial realism. Conn. Law Rev. 1992, 24, 363-379.

17. Crenshaw, K.W. Twenty years of Critical Race Theory: Looking back to move forward. Conn. Law Rev. 2011, 43, $1253-1352$.

18. Delgado, R.; Stefancic, J. Critical Race Theory: An Introduction; New York University Press: New York, NY, USA, 2012.

19. Logan, M.A. The Vote is Precious. Ind. JL Soc. Equal. 2016, 5, 105-132.

20. Delgado, R. Storytelling for oppositionists and others: A plea for narrative. Mich. Law Rev. 1989, 87, 2411-2441. [CrossRef]

21. Ladson-Billings, G.J.; Tate, W.F., IV. Toward a Critical Race Theory of education. Teach. Col. Rec. 1995, 97, 47-68. 
22. Solórzano, D.G.; Yosso, T.J. Critical race methodology: Counter-storytelling as an analytical framework for education research. Qual. Inq. 2002, 8, 23-44. [CrossRef]

23. Flaherty, C. Legislating Against Critical Race Theory. Inside Higher Ed. Available online: https://www.insidehighered.com/ news/2021/06/09/legislating-against-critical-race-theory-curricular-implications-some-states (accessed on 7 August 2021).

24. Kingkade, T. Critical Race Theory battles are driving frustrated, exhausted educators out of their jobs. NBC News. Available online: https:/ / www.nbcnews.com/news/us-news/critical-race-theory-battles-are-driving-frustrated-exhausted-educatorsout-n1273595 (accessed on 7 August 2021).

25. Map: Where Critical Race Theory Is Under Attack. EducationWeek. Available online: https://www.edweek.org/policy-politics/ map-where-critical-race-theory-is-under-attack/2021/06 (accessed on 7 August 2021).

26. Patton, L.D. Disrupting postsecondary prose: Toward a Critical Race Theory of higher education. Urban Ed. 2016, 51, 315-342. [CrossRef]

27. Critical Race Training in Education. Legal Insurrection Foundation. Available online: https://criticalrace.org/ (accessed on 7 August 2021).

28. Brewster, J. Trump Says Critical Race Theory Borders On ‘Psychological Abuse'. Forbes. Available online: https://www.forbes. $\mathrm{com} /$ sites/jackbrewster/2021/06/18/trump-says-critical-race-theory-borders-on-psychological-abuse/?sh=e971c78450e7 (accessed on 7 August 2021).

29. Stovall, D.; Annamma, S. Using Critical Race Theory to understand the backlash against it. The Hechinger Report. Available online: https:/ / hechingerreport.org/opinion-using-critical-race-theory-to-understand-the-backlash-against-it/ (accessed on 7 August 2021).

30. Inman, D. Marc Lamont Hill shuts down GOP's Vernon Jones on Critical Race Theory. The Grio. Available online: https: //thegrio.com/2021/05/05/marc-lamont-hill-vernon-jones-critical-race-theory-debate/ (accessed on 7 August 2021).

31. Solórzano, D.G.; Ceja, M.; Yosso, T. Critical Race Theory, racial microaggressions, and campus racial climate: The experiences of African American college students. J. Negro Ed. 2000, 69, 60-73.

32. Garcia, G.A.; Johnston-Guerrero, M.P. Challenging the utility of a racial microaggressions framework through a systematic review of racially biased incidents on campus. J. Crit. Scholarsh. High. Educ. Stud. Aff. 2015, 2, 48-66.

33. Sue, D.W. Microaggressions in Everyday Life: Race, Gender, and Sexual Orientation; John Wiley and Sons: Hoboken, NJ, USA, 2010.

34. Lilienfeld, S.O. Microaggressions: Strong claims, inadequate evidence. Perspect. Psych. Sci. 2017, 12, 138-169. [CrossRef] [PubMed]

35. Haidt, J. The unwisest idea on campus: Commentary on Lilienfeld (2017). Perspect. Psych. Sci. 2017, 12, 176-177. [CrossRef]

36. Sue, D.W. Microaggressions and "evidence" empirical or experiential reality? Perspect. Psych. Sci. 2017, 12, 170-172. [CrossRef] [PubMed]

37. Williams, M.T. Microaggressions: Clarification, evidence, and impact. Perspect. Psych. Sci. 2020, 15, 3-26. [CrossRef] [PubMed]

38. Williams, M.T. Psychology cannot afford to ignore the many harms caused by microaggressions. Perspect. Psych. Sci. 2020, 15, 38-43. [CrossRef]

39. Fleming, C.M.; Lamont, M.; Welburn, J.S. African Americans respond to stigmatization: The meanings and salience of confronting, deflecting conflict, educating the ignorant and 'managing the self'. Ethn. Racial Stud. 2012, 35, 400-417. [CrossRef]

40. Gong, F.; Xu, J.; Takeuchi, D.T. Racial and ethnic differences in perceptions of everyday discrimination. Soc. Race Ethn. 2017, 3, 506-521. [CrossRef]

41. Dancy, T.E.; Edwards, K.T.; Earl Davis, J. Historically white universities and plantation politics: Anti-Blackness and higher education in the Black Lives Matter era. Urban Ed. 2018, 53, 176-195. [CrossRef]

42. Maxouris, C. In Maryland, a white college student is convicted of killing a black US Army lieutenant. CNN. Available online: https: //www.cnn.com/2019/12/18/us/richard-collins-iii-maryland-student-stabbing-hate-crime-thrown-out/index.html (accessed on 7 August 2021).

43. Anderson, G. A racist attack at Arizona. Inside Higher Ed. Available online: https://www.insidehighered.com/news/2019/09/ 17 /arizona-students-criticize-university-police-response-alleged-assault (accessed on 7 August 2021).

44. Rodriguez, J. Roommate testifies in San Jose State bullying case. Santa Cruz Sentinel. Available online: https://www. santacruzsentinel.com/2016/02/08/roommate-testifies-in-san-jose-state-bullying-case/ (accessed on 7 August 2021).

45. Rodriguez, J. San Jose State dormitory battering: Sentence of 30 days in jail or weekend work. Santa Cruz Sentinel. Available online: https:/ / www.santacruzsentinel.com/2016/03/14/san-jose-state-dormitory-battering-sentence-of-30-days-in-jail-orweekend-work-2/ (accessed on 7 August 2021).

46. Coates, T. Playing the racist card: Ferraro's comments about Obama were racist. Why can't we say that? Slate. Available online: https:/ / slate.com/news-and-politics/2008/03/ferraro-s-comments-about-obama-were-racist-why-can-t-we-say-that. html (accessed on 7 August 2021).

47. Crenshaw, K.W. The first decade: Critical reflections, or a foot in the closing door. UCLA Law Rev. 2002, 49, $1343-1373$.

48. Quaye, S.J.; Karikari, S.N.; Carter, K.D.; Okello, W.K.; Allen, C. “Why can't I just chill?": The visceral nature of racial battle fatigue. J. Coll. Stud. Dev. 2020, 61, 609-623. [CrossRef]

49. Collins, P.H. Fighting Words: Black Women and the Search for Justice; University of Minnesota Press: Minneapolis, MN, USA, 1998. 